\title{
Relationship Between Social Support and High-Risk Relapse Situation among Drug Offenders
}

Fauziah Ibrahim, Ezarina Zakaria, Nazirah Hassan, Mohammad Rahim Kamaluddin, Wan Shahrazad Wan Sulaiman \& Nurul Atikah Yunos

To Link this Article: http://dx.doi.org/10.6007/IJARBSS/v12-i1/12176

DOI:10.6007/IJARBSS/v12-i1/12176

Received: 08 November 2021, Revised: 11 December 2021, Accepted: 24 December 2021

Published Online: 19 January 2022

In-Text Citation: (Ibrahim et al., 2022)

To Cite this Article: Ibrahim, F., Ezarina Zakaria, N. H., Kamaluddin, M. R., Sulaiman, W. S. W., \& Yunos, N. A. (2022). Relationship Between Social Support and High-Risk Relapse Situation among Drug Offenders. International Journal of Academic Research in Business and Social Sciences, 12(1), 1438 - 1444.

Copyright: (c) 2022 The Author(s)

Published by Human Resource Management Academic Research Society (www.hrmars.com) This article is published under the Creative Commons Attribution (CC BY 4.0) license. Anyone may reproduce, distribute, translate and create derivative works of this article (for both commercial and non0-commercial purposes), subject to full attribution to the original publication and authors. The full terms of this license may be seen at: http://creativecommons.org/licences/by/4.0/legalcode

Vol. 12, No. 1, 2022, Pg. 1438 - 1444

Full Terms \& Conditions of access and use can be found at http://hrmars.com/index.php/pages/detail/publication-ethics 


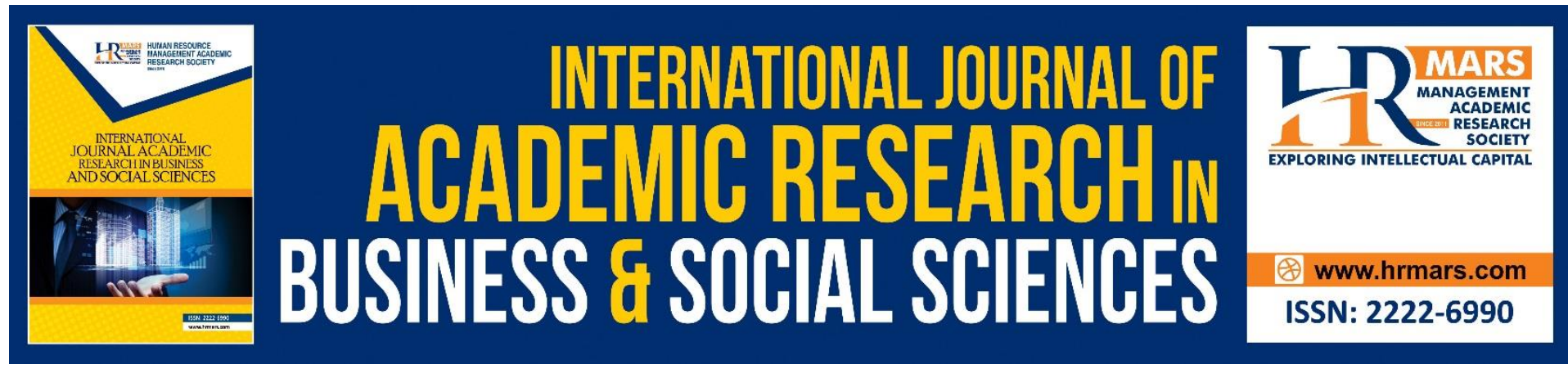

\title{
Relationship Between Social Support and High- Risk Relapse Situation among Drug Offenders
}

\author{
Fauziah Ibrahim, Ezarina Zakaria, Nazirah Hassan, \\ Mohammad Rahim Kamaluddin, Wan Shahrazad Wan \\ Sulaiman \& Nurul Atikah Yunos \\ Social Work Program, Center for Research in Psychology and Human Well-Being, \\ Faculty of Social Science and Humanities, Universiti Kebangsaan Malaysia, \\ 43600 Bangi, Selangor, Malaysia \\ Corresponding Author Email: ifauziah@ukm.edu.my
}

\begin{abstract}
Social support is an important aspect of the drug recovery process and helps prevent a person from re-engaging with relapse addiction. Therefore, this research was conducted to (1) identify the level of social support among drug offenders and (2) analyze the relationship between social support with high-risk relapse situations among drug offenders. The study was conducted using a cross-sectional survey using a quantitative design. A total of 407 prisoners involved in drug cases and undergoing detention and rehabilitation at Jabatan Penjara Malaysia (The Malaysian Prisons Department) were selected as study respondents. The data collected were analyzed using descriptive and Pearson correlation tests. The study results show that the majority of drug offenders undergoing rehabilitation and detention in Malaysian prisons receive social support at a moderate to high level. Pearson correlation analysis found that social support had a significant relationship with high-risk relapse situations. The research results have implications for stakeholders in improving more effective drug treatment and rehabilitation programs with the involvement and social support from family, friends and the local community.
\end{abstract}

Keywords: Drug Offender, Support, Social, Relapse, High-Risk

\section{Introduction}

Every individual need social support from their surroundings in a stressful situation. Social support is defined as an experience related to appreciation, attention, and affection (Gurung, 2006). According to Katc and Kahn (2000), social support is the positive feelings, joy, trust, and attention from others in an individual's life. Social support can be in the form of trust, attention and assistance to meet one's needs from someone close such as family, friends or employers. Good social support contributes to positive feelings, strength and helps to build a peaceful life. Usually, social support comes from family, friends, community and neighbours, or people who are significant to a person. The support gained can make a person feel more valued by the people around and become more motivated to move on to a better life. The most important support is from family members as they are the individuals closest to the 
former addict. Family is an important source of inspiration for former addicts to change and start a new life free from drug re-use behaviours (Normala \& Mohd, 2017). Poor support among family members can have a negative impact on the drug recovery process and cause a high potential of relapse among the addicts (Fauziah et al., 2009). Family support, close relationships and positive family attitudes can save ex-addicts from falling into the trap of readdiction (Budhatoki et al., 2006). This situation indicates that family support is essential to increase the confidence and self-resilience of addicts who constantly strive to live free from the risk of the drug (Fauziah et al., 2017; Ruhani et al., 2012). In short, trust and acceptance from the family can provide a good stimulus to the recovery process of ex-addicts. On the other hand, the lack of family support complicates the reintegration of ex-prisoners into community life (Beale \& Jones, 2004). Previous studies have found that poor communication and limited interaction can also cause an individual to become inclined to relapse-addiction (Mohd et al., 2000). Therefore, family support plays a vital role during the treatment and rehabilitation period to help ex-addicts from getting stuck with relapse addiction.

In addition to family support, peer support is also needed in the treatment and rehabilitation process, especially when ex-addicts lose support from family. According to Fauziah et al (2009), the strong support received from peers in terms of emotions and morale can increase the self-confidence of ex-addicts to maintain recovery. In contrast to the results of a study by Mohd et al (2018), who found that acceptance and compatibility with old friends, especially when they were alone, resulted in them being re-involved with drug addiction. The results of a study by Mohd, et al (2018) found that companions who are still addicted serve as a connection to buying and selling drugs or stolen goods as a source of funds to buy drugs. In fact, negative relationships, temptations, and pressures from ties with peers during the recovery period can stimulate former addicts to return to drug use (McCarty et al., 2010). In conclusion, good support from friends who have never been addicted will bring positive effects, while support from friends who were addicts will lead to adverse effects and return to drug usage.

Other than the support of family and friends, the support of neighbours and the surrounding community also plays an essential role in efforts to help ex-addicts recover. Neighbours are part of the community responsible for helping aspects of ex-addict recovery. In their study, Mohd \& Mahmood (2009) found that a caring society has a strong influence in curbing the problem of drug re-addiction. However, a minority in the community are too egocentric and refuse to cooperate but act to blame certain parties if any of their family members got involved with drugs (Norazleen \& Nurafifah, 2015). Such societal attitudes will make it difficult for ex-addicts to live a drug-free life due to skewed views and negative prejudices. Therefore, in addition to family and friends, society should play an important role in supporting exaddicts to recover and allow them to build a new life free from the influence of drugs. Good social support can make a person feel valued, loved, and attended to continue change, especially when faced with a stressful situation. In fact, the social support received by drug addicts can help them cope with any problems more effectively (Will \& Filer, 2001). Since social support is critical in helping recovery, this research was conducted to identify the level of social support received by drug prisoners and identify the extent of the relationship between social support and high-risk relapse situations. The research results are seen to help provide information as an important reference to improve drug rehabilitation programs in Malaysia. 


\section{Research Methodology}

Research Design: This research uses quantitative cross-sectional survey methods. It was conducted using a survey questionnaire. Quantitative research uses numerical data throughout the process, beginning from data collection, data interpretation and presentation of findings (Arikunto, 2006).

Research Population, Sample and Location: In this research, the population refers to drug offenders serving sentences in Malaysian Prisons. A total of 407 drug offenders placed in five prisons zones were selected as samples. Among the prisons involved in the research are from the southern zone (Melaka Prisons), the central zone (Selangor Prisons), the northern zone (Perak Prisons), the eastern zone (Pahang Prisons) and the Sabah / Sarawak zone (Prisons Sabah). All those involved in this research were: (1) Malay drug offenders serving time in prison for at least six months.

Research Instruments: The research instruments are as follows:

1. Social Support: This test tool was developed by Fauziah et al (2016) and comprised of 17 questions items to measure social support among prisoners. The scale of reliability value is high at 0.899 .

2. High risk of relapse situations: The test tool developed by Fauziah et al (2016) and consists of 3 parts that are related to social-environmental stress (9 items), interpersonal conflict (10 items) and negative emotions (10 items) used to measure the high risk of relapse situations among drug offenders. The reliability value of this scale is high at .885 .

Both instruments used in this study use a four-scale Likert Scale with a choice of answers, namely (1) strongly disagree, (2) disagree, (3) agree and (4) strongly agree.

Data Analysis: Data were analysed using the "Statistical Package for the Social Science for Windows" (SPSS for Windows). Descriptive analysis such as frequency, mean, mode, median, percentage and standard deviation were used to measure social support by drug offenders. On the other hand, inference analysis (correlation test) is used to measure the relationship between social support with high-risk situations of relapse among drug offenders. The interpretation of this correlation relationship is based on Guildford's (1973) Rule of Thumb' as in Table 21 below:

Table 1: The Interpretation of strength of correlation based on Guildford's (1973) Rule of Thumb'

\begin{tabular}{cl}
\hline Pearson Correlation $(\mathbf{r})$ & Strength of Relationship \\
\hline$<.20$ & Slight relationship \\
.20 to .40 & Low correlation \\
.41 to .70 & Moderate correlation \\
.71 to .90 & High correlation \\
$>.90$ & Very high correlation \\
\hline
\end{tabular}

\section{Findings and Discussion}

The results showed that the majority of drug offenders serving sentences in Penjara Malaysia (Malaysian prisons) received social support at a moderate level (50.6\%) to a high level (46.7\%). Only $2.7 \%$ of drug offenders received low levels of social support. 
Table 2: Level of Social Support

\begin{tabular}{lll}
\hline Level & $\mathbf{N}=\mathbf{4 0 7}$ & Percentage (\%) \\
\hline Low & 11 & 2.7 \\
Moderate & 206 & 50.6 \\
High & 190 & 46.7 \\
\hline TOTAL & & $\mathbf{1 0 0}$ \\
\hline
\end{tabular}

Note: Low level (1.00-2.00) Moderate Level (2.01-3.00) High Level (3.01-4.00)

The results of this study give the impression that social support among drug offenders is satisfactory and can help them be free from drug problems and start a new life after release from prison. According to Drageset (2004), if an individual obtains good social support from family members and friends, the individual is more confident to start a new life and has a place to express problems. Good social support can make a person feel valued, loved and attended to pursue positive life changes, especially in a stressful situation (Gurung, 2006). Good social support can also help ex-addicts cope more effectively (Will \& Filer, 2001). Individuals who fail to obtain social support can cause them to feel inferior, unappreciated and, in turn, can lead to depression (Wong, 2002). This state of depression and negative emotions, if not addressed, can lead to the risk of drug re-addiction (Fauziah, 2016).

\section{Relationship Between Coping Strategies and High-Risk Relapse Situations}

The analysis showed a negative, weak, and significant relationship between social support ( $r$ $=.258^{* *}, \mathrm{k}<0.00$ ) with high-risk relapse situations among drug offenders serving sentences in Penjara Malaysia (Malaysian Prisons). This negative relationship suggests that the higher the social support received, the lower the high-risk relapse situation among drug offenders. Therefore, based on these results, this research accepts the research hypothesis that predicts a significant relationship between social support and high-risk relapse situations among drug prisoners in Malaysian Prisons.

Table 3: The Relationship between Social Support and High -Risk Relapse Situations.

\begin{tabular}{lcc}
\hline Variables & \multicolumn{2}{c}{ High -Risk Relapse Situations } \\
\cline { 2 - 3 } & Correlation Value $(\mathrm{r})$ & Significant Level $(\mathrm{k})$ \\
\hline Social Support & $-.258^{* *}$ & .000 \\
\hline Note: ${ }^{* *}$ significant at the 0.01 confidence level
\end{tabular}

The results of this research give the impression that social support plays a vital role due to its relationship with high-risk relapse situations. Social support, especially among family members, plays an important role because they are the closest individuals to a person who can provide moral support and motivation for recovery (Normala \& Mohd, 2017). Poor social support among family members has a negative impact on the drug recovery process of the drug offenders and has a high potential for them to fall into relapse (Fauziah et al., 2009).

\section{Conclusion}

Good social support is part of the drug treatment and rehabilitation process. Social support can help increase self-confidence and motivate a person involved with drugs to rise and start a new life. In summary, the research found that the majority of prisoners involved with drugs received satisfactory social support from their family, friends and neighbours. This good support predicts a positive recovery process, shapes a blissful life, and can help those who 
have been involved with drugs to start a new life. The research results also found that social support had a significant relationship with high-risk relapse situations. The higher the social support, the lower the risk of an individual getting involved again with relapse addiction. The results of this research have important implications for stakeholders, especially drug rehabilitation counsellors, psychologists and social workers involved in the drug treatment and rehabilitation.

\section{Acknowledgement}

The researchers would like to acknowledge the Ministry of Higher Education (MOHE) (FRGS/1/2018/SS06/UKM/02/2) for funding this research. Appreciation is also extended to the Malaysian Prison Department, Faculty of Social Sciences and Humanities, UKM, and everyone who has contributed to the completion of this study.

\section{References}

Arikunto, S. (2006). Prosedur Penilaian Suatu Pendekatan Praktik. Edisi ke-6. Jakarta: Penerbit PT Rineka Cipta.

Beale, S. M., \& Jones, W. C. (2004). Interventions and service offered to former juvenile offenders reentering their communities. Youth Violence and Juvenile Justice, 2(1): 8897.

Budhathoki, N., Shrestha, M. K., Acharya, N., \& Manandhar, A. (2010). Substance use among third year medical students of Nepal. Journal of Nepal Health Research Council.

Drageset, J. (2004). The importance of activities of daily living and social contact for loneliness: A survey among residents in nursing homes. Scandinavian Journal of Caring Sciences,18(1), 65-71

Fauziah, I., Bahaman, A. S., Mansor, A. T., \& Mohd, S. S. (2009). Faktor menyumbang kepada penagihan relaps dalam kalangan penagih dadah PUSPEN di Semenanjung Malaysia. Jurnal Agensi Antidadah Kebangsaan, 5:235-251.

Fauziah, I., Ezarina, Z., Nor, J. S., Salina, N., \& Mohd, N. M. S. (2017). Faktor-faktor penyumbang ketahanan diri penagih untuk pulih bebas dadah. Journal of Social Science and Humanities, Vol. 12(1):60-74.

Fauziah, I., Ezarina, Z., Salina, N., Norulhuda, S., Siti, M. M. (2016). Kecenderungan relaps dan kejayaan mengekalkan kepulihan dalam kalangan penghuni yang tamat mengikuti rawatan dan pemulihan di Cure \& Care Rehabilitation Centre (CCRC). Laporan Akhir Penyelidikan: Geran Penyelidikan IImiah AADK.

Gurung, R. A. R. (2006). Health psychology: A cultural approach. Belmont, CA: Thomson Wadsworth.

Mohd, T., Rusli \& Mohd, K. (2000). Pola-pola komunikasi kekeluargaan: Kajian di kalangan keluarga penagih dan bukan penagih di negeri Kedah. Penyelidikan Sekolah Pembangunan Sosial.

Mohd, A. J., Siti Hajar, A. B., Ah, J. Z., Khairiyah, M. S., Noralina, O., \& Zaiton, A. (2018). Kekurangan akses kepada jagaan lanjutan dan faktor-faktor risiko yang membawa kepada relaps dadah dalam kalangan bekas banduan. Jurnal Perspektif Jil. 10 (Bil.2): 3444.

Mohd, A. M. N., \& Mahmood, N. M. (2009). Faktor-faktor yang mempengaruhi kecenderungan bekerja penghuni pusat pemulihan penagihan narkotik (PUSPEN). Jurnal Antidadah Malaysia, 5(1): 1-29 
McCarty, D., Perrin, N. A., Green, C. A., Polen, M. R., Leo, M. C., \& Lynch, F. (2010). Methadone maintainance and the cost and utilization of health care among individuals dependent on opioids in a commercial health plan. Drug and Alcohol Dependence, 111(3): 235-240.

Norazleen, M. M., \& Nurafifah, K. (2015). Kerinduan atau Ketagihan terhadap Dadah: Punca Belia Kecundang dan Kembali Menagih. International Drug Prevention and Rehabilitation Conference.

Normala, A. B., \& Azhar, M. A. H. (2017). Kepentingan peristiwa pencetus dalam transformasi perspektif bekas penagih dadah. Sains Humanika 9:1-5

Ruhani, M. M., Abdullah, M., \& Ezdianie, N. O. (2012). Keperibadian dan sokongan sosial penghuni PUSPEN: Implikasi terhadap program pemulihan. Jurnal Kemanusiaan, 10(2).

Wills, T. A., \& Filer, M. (2001). Social networks and social support. In A. Baum, T. A. Revenson, \& J. E. Singer (Eds.), Handbook of health psychology (pp. 209-234). Mahwah, NJ: Erlbaum.

Wong, M. T. (2002). Hubungan di antara sokongan sosial dengan kemurungan di kalangan remaja. Tesis tidak diterbitkan. UKM 